\title{
Bilateral pneumothorax complicated by extraperitoneal air
}

\author{
Dianne van Beek, ${ }^{1}$ Nicole Fernandes, ${ }^{2}$ Mark Hazekamp, ${ }^{3}$ Karin Hogenbirk ${ }^{1}$
}

${ }^{1}$ Pediatric Intensive Care Unit, Leiden University Medical

Center, Leiden,

The Netherlands

${ }^{2}$ Department of Radiology, Leiden University Medical

Center, Leiden,

The Netherlands

${ }^{3}$ Department of Cardiothoracic

Surgery, Leiden University

Medical Center, Leiden,

The Netherlands

Correspondence to

Dr Dianne van Beek,

e.c.vanbeek-8@umcutrecht.nl

Accepted 10 August 2014

\section{DESCRIPTION}

An 11-month-old male child with Down syndrome was admitted to the pediatric intensive care unit (PICU) after an uncomplicated correction of his complete atrioventricular septal defect. On postoperative day 5 , there was an acute incident after administration of an enema which started with a decrease in tidal volumes. Eventually, there was no air entry, resulting in desaturation and subsequently a bradycardia with no cardiac output. Cardiopulmonary resuscitation was started. The abdomen of the patient was distended. The differential diagnosis included tension pneumothorax and abdominal perforation. A bilateral needle decompression was performed immediately. This temporarily resulted in improved ventilation and disappearance of the abdominal distention. The X-ray showed a bilateral pneumothorax with air located in the anterior extraperitoneal space in the abdomen (figure 1). The cardiothoracic surgeon inserted pleural drains bilaterally, resulting in lasting improvement. The patient was discharged from the PICU in good clinical condition 10 days after the incident.

Extraperitoneal air without intraperitoneal air is very rare and can easily be mistaken for air in the intraperitoneal cavity. ${ }^{1}$ It results from extravasation of air from the thoracic cavity to the area between the parietal peritoneum and the transversalis fascia. This route might have resulted from the mediastinal drain that was in place the first postoperative days.

\section{Learning points}

- In a CPR setting it can be challenging to distinguish between extraperitoneal and intraperitoneal air.

- Mediastinal drains can create a root from the thoracic cavity to the space between the parietal peritoneum and transversalis fascia.

- Extraperitoneal air is a rare complication of a (bilateral) pneumothorax.

CrossMark

To cite: van Beek $D$, Fernandes N, Hazekamp M, et al. BMJ Case Rep Published online: [please include Day Month Year] doi:10.1136/bcr-2014205463

\section{Competing interests None.}

Patient consent Obtained.

Provenance and peer review Not commissioned; externally peer reviewed.

\section{REFERENCE}

1 Balthazar EJ, Moore SL. CT evaluation of infradiaphragmatic air in patients treated with mechanically assisted ventilation: a potential source of error. AJR Am J Roentgenol 1996:(3):731-4.
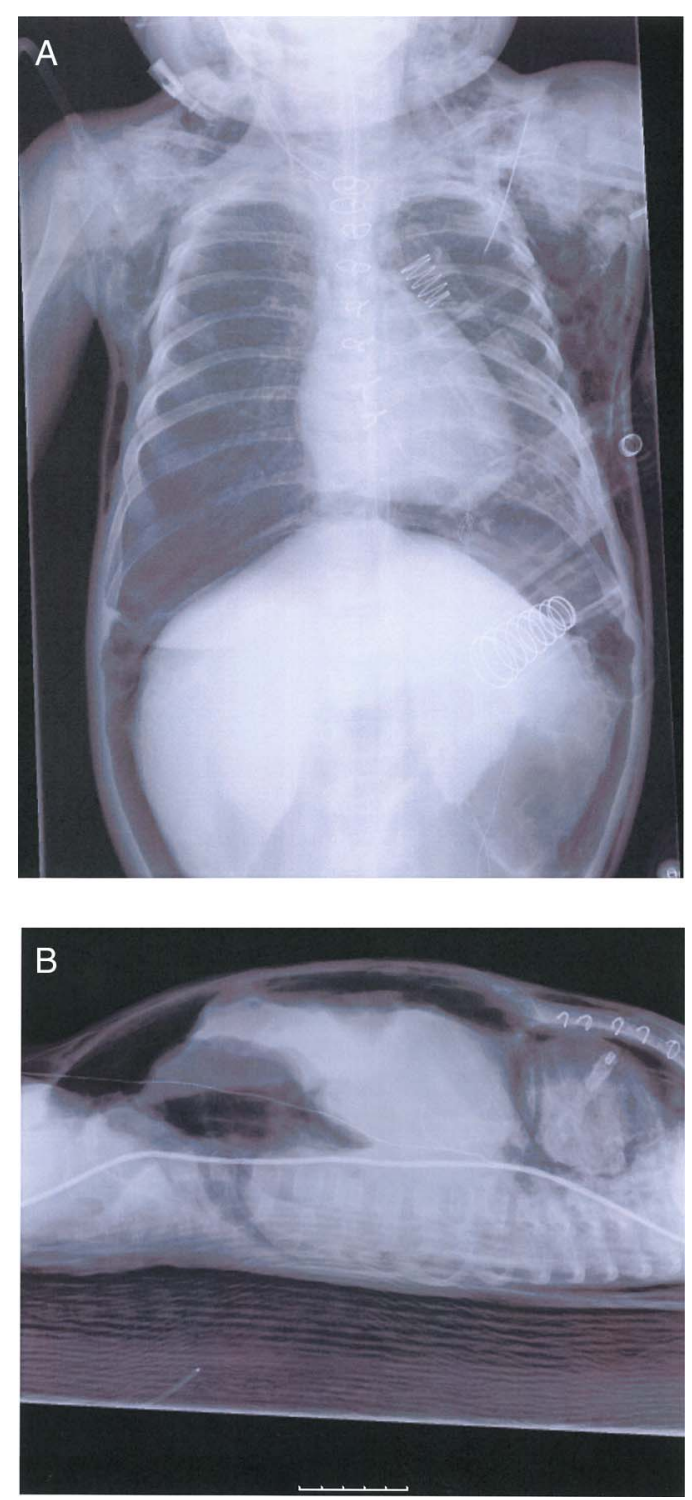

Figure 1 Thoracoabdominal radiograph (A) anteroposterior and (B) lateral view (Radiology Department, Leiden University Medical Center, Leiden, The Netherlands). Sternal sutures, endotracheal tube, epicardial leads, nasogastric tube and central venous line in right $v$. jugularis in good position. Subcutaneous emphysema in the neck, thoracic wall and left abdominal wall. Bilateral basal pneumothorax. Air alongside the internal linings of the abdominal wall. No radiological signs of a pneumoperitoneum (Rigler sign, Falciform ligament sign, Football sign). 
Copyright 2014 BMJ Publishing Group. All rights reserved. For permission to reuse any of this content visit http://group.bmj.com/group/rights-licensing/permissions.

BMJ Case Report Fellows may re-use this article for personal use and teaching without any further permission.

Become a Fellow of BMJ Case Reports today and you can:

- Submit as many cases as you like

- Enjoy fast sympathetic peer review and rapid publication of accepted articles

- Access all the published articles

- Re-use any of the published material for personal use and teaching without further permission

For information on Institutional Fellowships contact consortiasales@bmjgroup.com

Visit casereports.bmj.com for more articles like this and to become a Fellow 